\title{
THE RESIDUAL EFFECT OF DELTAMETRINE IN THE CONTROL OF MALARIA AS OBSERVED ON DIFFERENT TYPES OF WALLS IN THE BRAZILIAN AMAZON
}

\author{
Regina FIGUEIREDO ${ }^{2}$, Wanderli P. TADEI ${ }^{2}$, Bedsy DUTARY THATCHER ${ }^{2}$
}

\begin{abstract}
The residual power of deltametrine FW $\left(25 \mathrm{mg} 1 . \mathrm{a} / \mathrm{m}^{2}\right)$ was evaluated and compared to that of DDT $\left(2 \mathrm{~g}\right.$ i.a. $\left./ \mathrm{m}^{2}\right)$ by means of biological tests. The different kinds of material used in constructing houses in Amazonia, such as: masonry, wood, and wattle and daub, were used. Data from logistic regression showed that the drop in mortality, the inclination of the curve in relation to time, was similar for the two insecticides in the first samples. The negative coeficient for the variable, months after application, confirmed a reduction in the activity of both insecticides. Wooden and wattle walls showed positive and negative coeficiencies respectively from the beginning. The wooden walls retained a residual effect but the wattle walls were shown to be the least indicated for the application of insecticides The experiments demonstrated a more prolonged residual effect for deltametrine as compared to DDT, and that insecticides work better on brick and cement and wooden walls than they do on wattle and daub constructions. For these reasons, it would be necessary to spray brick and cement walls every 8 months, wooden ones every 9 months and wattle constructions every 7 months to control the vectors of malaria.
\end{abstract}

Key words: Malaria Control, Deltametrine, Masonry, Wood, Wattle and Daub.

\section{O Efeito Residual de Deltametrina no Controle da Malária Observado sobre Diferentes} Tipos de Paredes na Amazônia Brasileira.

RESUMO - O poder residual da deltametrina FW $\left(25 \mathrm{mg}\right.$ i.a. $\left./ \mathrm{m}^{2}\right)$ foi avaliado e comparado com o DDT $\left(2 \mathrm{~g}\right.$ i.a. $\left./ \mathrm{m}^{2}\right)$, por meio de provas biológicas. Foram utilizados diferentes tipos de materiais frequentemente usados na construção de casas na Amazônia: alvenaria, madeira e taipa. Os dados da regressão logística evidenciaram que a queda da mortalidade, inclinação da reta em relação ao tempo é semelhante para os dois inseticidas, nas primeiras amostragens. O coeficiente negativo para a variável Meses após aplicação confirma a redução de atividade de ambos os inseticidas. A madeira e a taipa apresentam coeficientes positivos e negativos respectivamente, desde o tempo zero, demonstrando a contribuição positiva do primeiro substrato em ambos intervalos de tempo, e o segundo como o menos indicado para a aplicação dos inseticidas. Os testes mostraram o efeito residual mais prolongado da deltametrina em relação ao DDT, sendo a madeira e a alvenaria substratos de melhor atuação dos inseticidas, em relação à taipa. Os resultados globais de mortalidade indicam que o ciclo semestral de borrifação pode ser estendido para 8 meses na alvenaria, 9 meses na madeira e 7 meses na taipa.

Palavras chaves: Controle da malária, Deltametrina, Alvenaria, Madeira, Taipa

\section{INTRODUCTION}

In Brazil, according to recent estimates (Marques \& Cardenas, 1994), about 152,669 people live in areas of continuous malaria transmission and 5,400,000 live in high risk areas found in the the following states of greater Amazonia: Acre,
Rondônia, Amazonas, Roraima, Amapá, Pará, Maranhão, Mato Grosso and Tocantins. In 1993, these areas were responsable for $85 \%$ of the malaria cases registered in the country. Of the 483,300 people who were found by the FNS (National Health Foundation) to be carrying plasmodia, 479,100 , or $91 \%$ of that

1 Trabalho subvencionado CNPq/Quimio.

2 Instituto Nacional de Pesquisas da Amazônia CPCS, Caixa Postal 478, CEP 69011-970 Manaus, Am. BRASIL. 
total, were from Amazonia (Marques \& Carrdenas, 1994).

The opening of new frontiers for development in Amazonia produced profound changes that altered the organismenvironment relationships. The enormous size of the dams and reservoirs attract large human populations to the vicinity of the construction sites (Tadei et al., 1983). Also, the uncontrolled and improvised activities in the pit mines result in an intense contact between miners and populations of Anopheles which make mosquito control measures virtually impossible (Tadei et al., 1988).

In the Amazonian region, the traditional control methods, based on intradomicilliary spraying and treatment of human cases, do not achieve the same results as in areas of high populational density and elevated indices of social and economic development (such as the South and Southeast of Brazil). Considering the conditions in the tropics, where habitats favors high densities of mosquito populations, it is necessary to utilize a wider spectrum of control strategies. Also, different parameters in relation to the vector must be taken into account (PAHO/ WHO, 1991; Tadei, 1993).

In spite of the fact that Amazonia is an endemic area for malaria and there are permanent campaigns which attempt to prevent it by eliminating the vectors, there is a lack of information about the effectiveness of piretroides under tropical conditions and in Amazonian houses.

In the present study, the residual power of deltametrine FW ( $25 \mathrm{mg}$ i.a. $/ \mathrm{m}^{2}$ ) was evaluated in comparison to that of DDT $2 \mathrm{~g}$ i.a. $/ \mathrm{m}^{2}$ ) by means of biological tests during 360 days on materials frequently used in house construction in the Amazon, namely: brick and cement; wood; and wattle and daub.

\section{MATERIAL AND METHODS}

In the present study, three experimental houses were built in an isolated location on the INPA(National Institute for Amazonian Research) campus. The houses were made of the material that is most often used in Amazonia: masonry; wood; and wattle daub (Fig. 1). The houses were sprayed utilizing a suspension of aqueous K-Othrine Flow-SC50 (Deltamethrine 5\%) at a concentration of $25 \mathrm{mg}$ i.a. $/ \mathrm{m}^{2}$. The dilution was $125 \mathrm{ml} / 10$ liters of water. The DDT was used in the form of a wettable powder at a concentration of $2 \mathrm{~g}$ i.a. $/ \mathrm{m}^{2}$.

For the biological tests, unfed female anophelines were collected monthly in a cattle corral located on BR-174 (Manaus-Boa Vista highway). The biological experiments to test the residual effects of deltametrine on walls were carried out in accordance with WHO (1975) recommendations.

\section{RESULTS AND DISCUSSION}

On the masonry (Tab. 1), the DDT showed higher mortality percentages up to 60 days than did the deltametrine and then its activity began to decline. On that type of wall, the deltametrine did not cause $100 \%$ mortality and the effect of both insecticides diminished greatly at 180 days. No residual effect remained for either insecticide after 360 days.

On wooden walls (Tab. 1), it was seen that, except for the 30 day period when DDT showed $100 \%$ mortality, the action of the deltametrine was actually superior. It lost its effect more slowly 


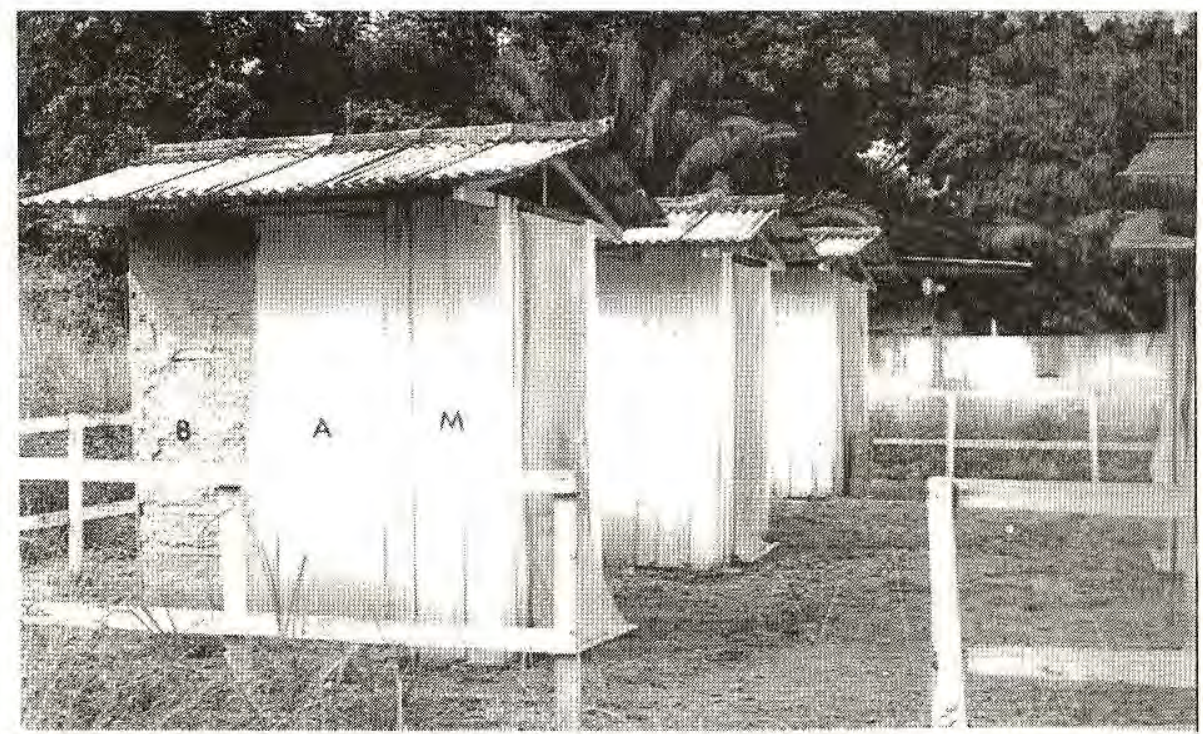

Figure 1. $b=$ mud; $a=$ masonry and $m=$ wood's houses in the experimental area.

Table 1. Anopheline mortalities obtained on masonry and wooden walls sprayed with DDT or deltametrine in Manaus between April, 1994 and March, 1995.

\begin{tabular}{|c|c|c|c|c|c|c|c|c|c|c|c|c|}
\hline \multirow{3}{*}{$\begin{array}{l}\text { Days } \\
\text { after } \\
\text { treat } \\
\text { ment }\end{array}$} & \multicolumn{6}{|c|}{ Number of anophelines tested/surface } & \multicolumn{6}{|c|}{ MORTALITY } \\
\hline & \multicolumn{3}{|c|}{ MANSORY } & \multicolumn{3}{|c|}{ WOOD } & \multicolumn{3}{|c|}{ MANSONAY } & \multicolumn{3}{|c|}{ WOOD } \\
\hline & FW & DDT & C & FW & DDT & C & FW & DDT & C & $\mathrm{FW}$ & DDT & c \\
\hline 30 & 150 & 150 & 30 & 150 & 150 & 30 & $147(98,00)$ & $151(100,00)$ & 0 & $147(98,00)$ & $150(100,00)$ & 0 \\
\hline 60 & 151 & 152 & 30 & 150 & 151 & 30 & $137(90,77)$ & $152(100,00)$ & 0 & $148(98,67)$ & $145(96,01)$ & 0 \\
\hline 90 & 150 & 150 & 30 & 150 & 150 & 30 & $120(80,00)$ & $125(83,33)$ & 0 & $141(94,00)$ & $127(84,67)$ & 0 \\
\hline 120 & 150 & 151 & 30 & 151 & 150 & 30 & $146(97,33)$ & $133(88,08)$ & 0 & $147(97,22)$ & ${ }^{*} 137(91,05)$ & *1 \\
\hline 150 & 152 & 149 & 30 & 150 & 149 & 30 & $136(89,49)$ & $128(85,89)$ & 0 & $146(97,33)$ & $134(89,93)$ & 0 \\
\hline 180 & 149 & 151 & 30 & 149 & 150 & 30 & $139(93,31)$ & $121(80,20)$ & 0 & $127(85,20)$ & $139(92,67)$ & 0 \\
\hline 210 & 150 & 149 & 30 & 150 & 149 & 30 & $97(64,59)$ & $70(46,80)$ & 0 & $140(92,30)^{*}$ & $124(80,62)$ & $* 2$ \\
\hline 240 & 150 & 149 & 30 & 147 & 150 & 30 & $77(51,36)$ & $71(47,75)$ & 0 & $89(60,59)$ & $88(58,67)$ & 0 \\
\hline 270 & 149 & 149 & 30 & 150 & 149 & 30 & $64(42,82)$ & $66(41,52)$ & 0 & $95(61,96)$ & $85(55,71)$ & ${ }^{* 1}$ \\
\hline 300 & 150 & 151 & 30 & 150 & 149 & 30 & $33(19,47)^{*}$ & $30(17,68)^{*}$ & 1 & $56(37,33)$ & $71(47,65)$ & 0 \\
\hline 330 & 151 & 148 & 30 & 150 & 148 & 30 & $10(0)^{\star}$ & $9(0)$ & ${ }^{*} 1$ & $52(34,67)$ & $45(30,40)$ & 0 \\
\hline 360 & 148 & 150 & 30 & 148 & 148 & 30 & $14(0)^{*}$ & $19(0)$ & $\cdot 2$ & $48(32,58)$ & $32(21,62)$ & 0 \\
\hline TOTAL & 1800 & 1799 & 360 & 1795 & 1793 & 360 & $1120(62,22)$ & $1075(59,75)$ & 4 & $1336(74,42)$ & $1277(7122)$ & \\
\hline
\end{tabular}
( ) = Percentage
()$^{*}=$ Percentage corrected by Abbott's formula
$\mathrm{FW}=$ aqueus deltametrine $(5 \%)$ 
and had an abrupt drop in activity only after 210 days. On this type of wall, both insecticides continued to show high mortality percentages up to 360 days after treatment. By comparing the two types of walls, it can be seen that the insecticides were about $20 \%$ more effective on the wood than on the masonry.

On wattle/daub walls, neither insecticide reached a level of $90 \%$ mortality at 30 days. Both insecticides gradually improved their effectiveness at 150 days post application (Tab. 2). After 210 days, the activity of both insecticides was reduced but that of detaltametrine remained about two and one-half times that of DDT.

Thirty minutes after exposure
(Tab. 3) the coeficients for the variables Months after application/Surface and Months after application/Insecticide were: masonry, -0.502 ; wattle, 0.523 ; and DDT, -0.991 , all negative values while for wood $(+0.073)$ and for deltametrine $(+0.991)$ positives were seen. These figures indicate three things, namely: 1 . The activity of both insecticides dropped off. 2. The greatest potential of deltametrine was shown after 30 minutes and the major activity of DDT after 24 hours. 3 . Wood is the best substrate of the three in maintaining insecticide activity.

After 24 hours (Tab. 3), for ther variable Months after application, a negative coefficient $(-0.450)$ confirmed a

Table 2. Anopheline mortalities obtained on wattle/daub walls sprayed with DDT or deltametrine in Manaus, between April, 1994 and May, 1995.

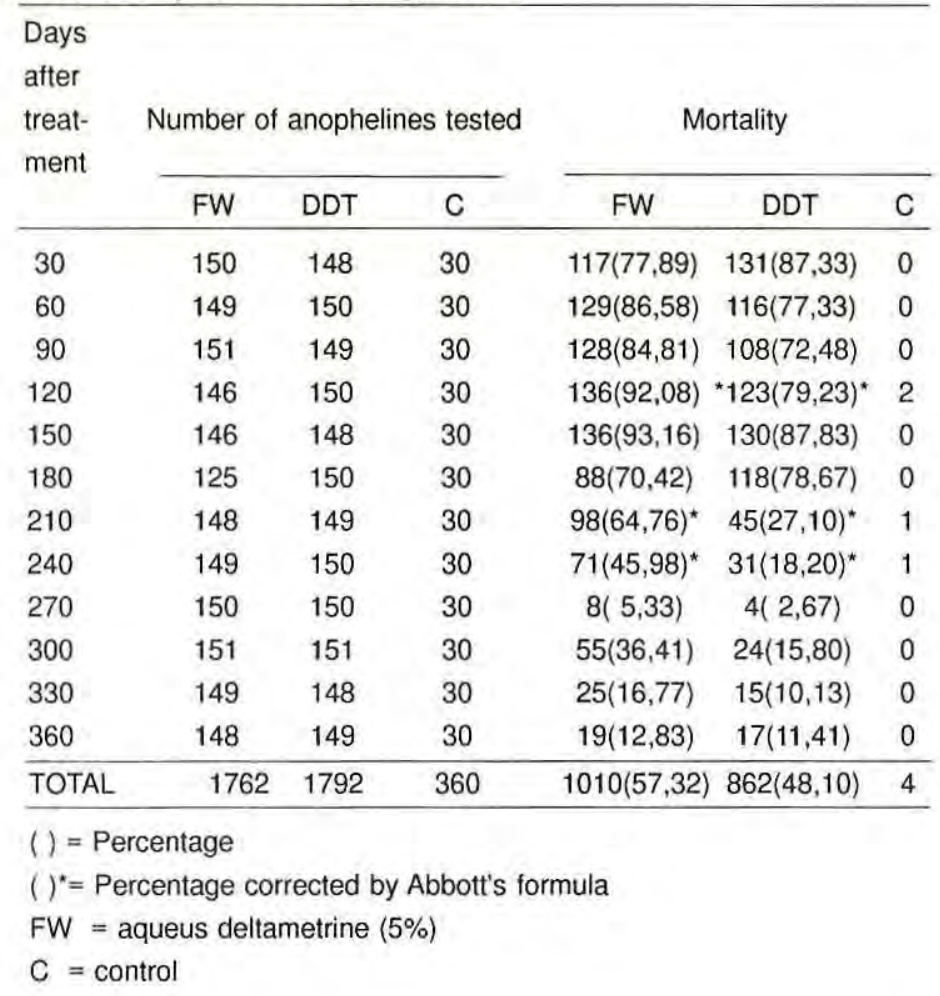


Table 3. Coefficients predicted by regression analysis of the variables that were significant for the mortality of Anopheles nuneztovari after 30 minutes and 24 hours.

\begin{tabular}{|c|c|c|c|c|c|c|}
\hline \multirow[t]{2}{*}{ Variable } & \multicolumn{2}{|c|}{ Coefficient } & \multicolumn{2}{|c|}{$\begin{array}{l}\text { Standard } \\
\text { deviation }\end{array}$} & \multicolumn{2}{|c|}{ Similarity Index } \\
\hline & $30^{\prime}$ & $24 h$ & $30^{\prime}$ & $24 h$ & $30^{\prime}$ & $24 h$ \\
\hline Months after application & $-0,297$ & $-0,450$ & 0,0069 & 0,009 & $1310,2(1)$ & $3933,0(1)$ \\
\hline Surface & & & & & $297,4(3)$ & $82,2(3)$ \\
\hline $\begin{array}{l}\text { Masonry } \\
\text { Wood } \\
\text { Wattle/Daub }\end{array}$ & $\begin{array}{r}-0,502 \\
0,073 \\
-0,523\end{array}$ & $\begin{array}{c}0,492 \\
0,612 \\
-0,884\end{array}$ & $\begin{array}{l}0,0488 \\
0,0436 \\
0,0476\end{array}$ & $\begin{array}{l}0,129 \\
0,137 \\
0,048\end{array}$ & & \\
\hline Insecticide & & & & & $1733,1(1)$ & $493,4(1)$ \\
\hline $\begin{array}{l}\text { DDT } \\
\text { Deltametrine } \\
\text { Months after application } \times \text { superface } \\
960,2(3)\end{array}$ & $\begin{array}{r}-0,991 \\
0,991\end{array}$ & $\begin{array}{c}-0,509 \\
0,505\end{array}$ & 0,0292 & 0,026 & & \\
\hline $\begin{array}{l}\text { Masonry } \\
\text { Wood } \\
\text { Wattle/Daub }\end{array}$ & - & $\begin{array}{l}-0,126 \\
-0,031 \\
-0,007\end{array}$ & & $\begin{array}{l}0,016 \\
0,016 \\
0,014\end{array}$ & & \\
\hline
\end{tabular}

reduction in the activity of both insecticides, which had already been detected at 30 minutes. With regard to surfaces, the masonry showed a positive coefficient $(+0.4919)$, which was the reverse of what had been seen at 30 minutes. The wood showed a positive coefficient $(+0.073 /$ $+0.6115)$ and the wattle a negative one $(-$ $0.523 /-0.8836$ ) from the start of the experiment. This demonstrates the positive contribution of the first substrate in both time intervals (30 minutes and 24 hours). It also shows that the wattle/daub surface is the least efficient for the application of insecticides. However, the coeffficients for the interaction of Months after application $\mathrm{x}$ Surface are all negative for the three surfaces indicating a drop in mortality on all of them with the passage of time. For the interaction Months after application $\mathrm{x}$ Insecticide, a negative coefficient for DDT $(-0.509)$ and a positive one for deltametrine $(+0.505)$ confirms the superiority of the latter in this time interval.

When we look at the mortality indices given in Figure 2/4, we can see that in the first two tests ( 30 and 60 days after application), the DDT produced a mortality superior to that of deltametrine on masonry (Fig. 2). The same occurred on wood and on dwattle/daub (Figs. 3, 4), after 30 days, but after 60 days the DDT began losing its activity more rapidly that did the deltametrine. For wood (Fig. 3), the mortality indices for DDT dropped from more than 150 after 30 days to values between 9 and 20 at 60 days and fell even further after 210 days. Deltametrine, on the other hand, maintained values between 50 and 70 up to 210 days. After that, the values for both insecticides dropped from about 5 to 1 after 360 days. On the wattle/daub (Fig. 4), the DDT showed indices below 10 up to 180 days but these increased to about 40 at 120 and 150 days. After 180 days, both insecticides showed a drop in mortality with values below 0.1 at 270 days. However, even at these low values, deltametrine showed levels of mortality superior to those of DDT.

In any case, when the mortality 


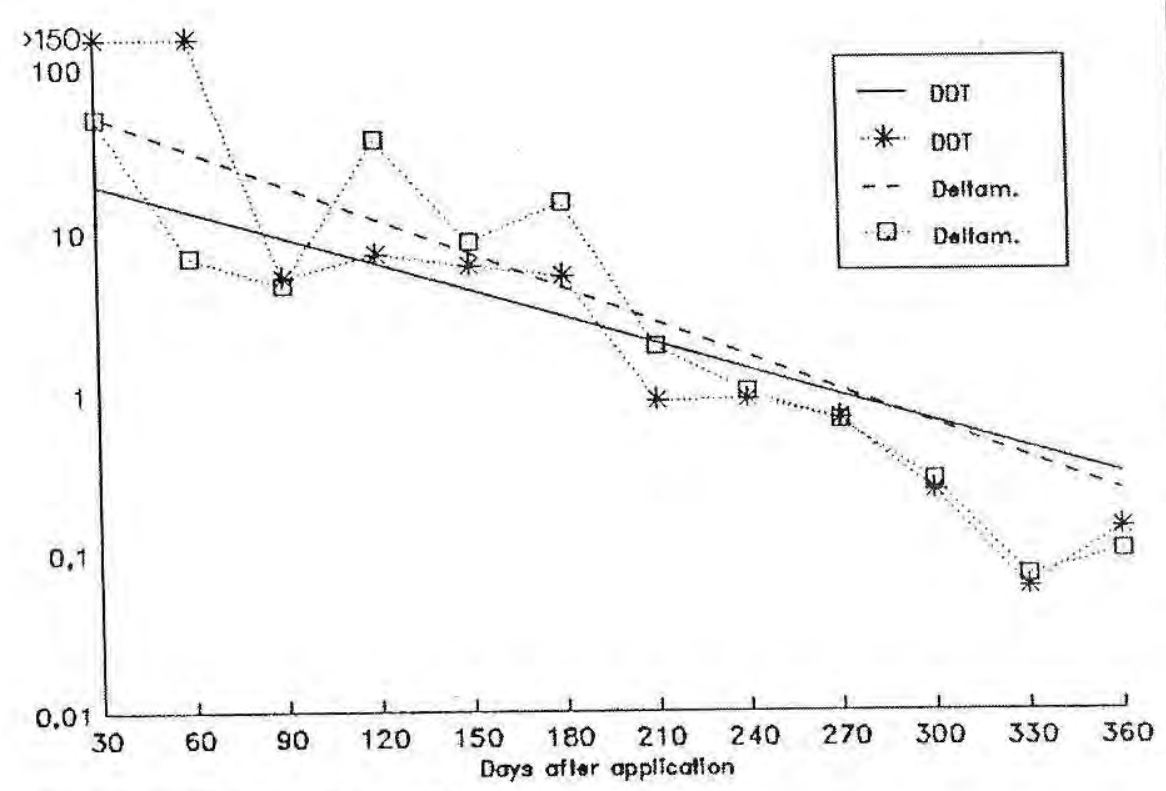

The IInes Indlcate loglstio regreselon ourves

Figure 2. Mortality indices on masonry at 24 hours.

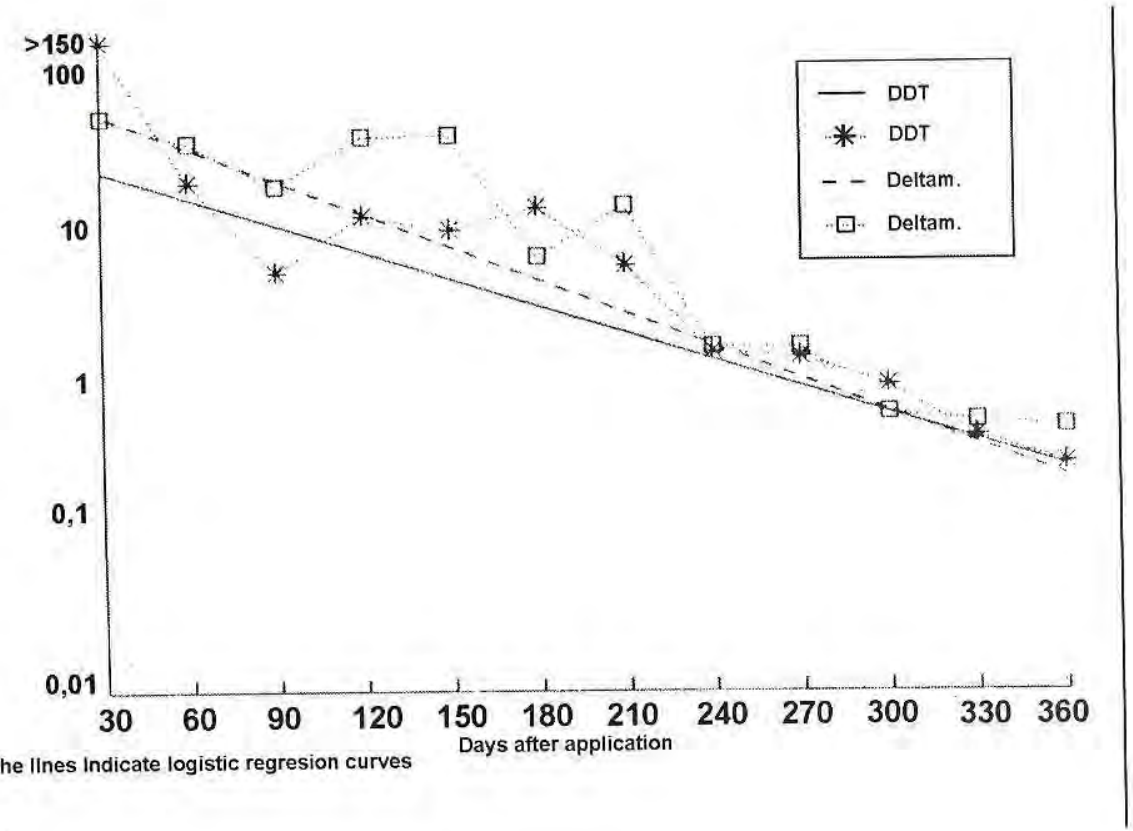




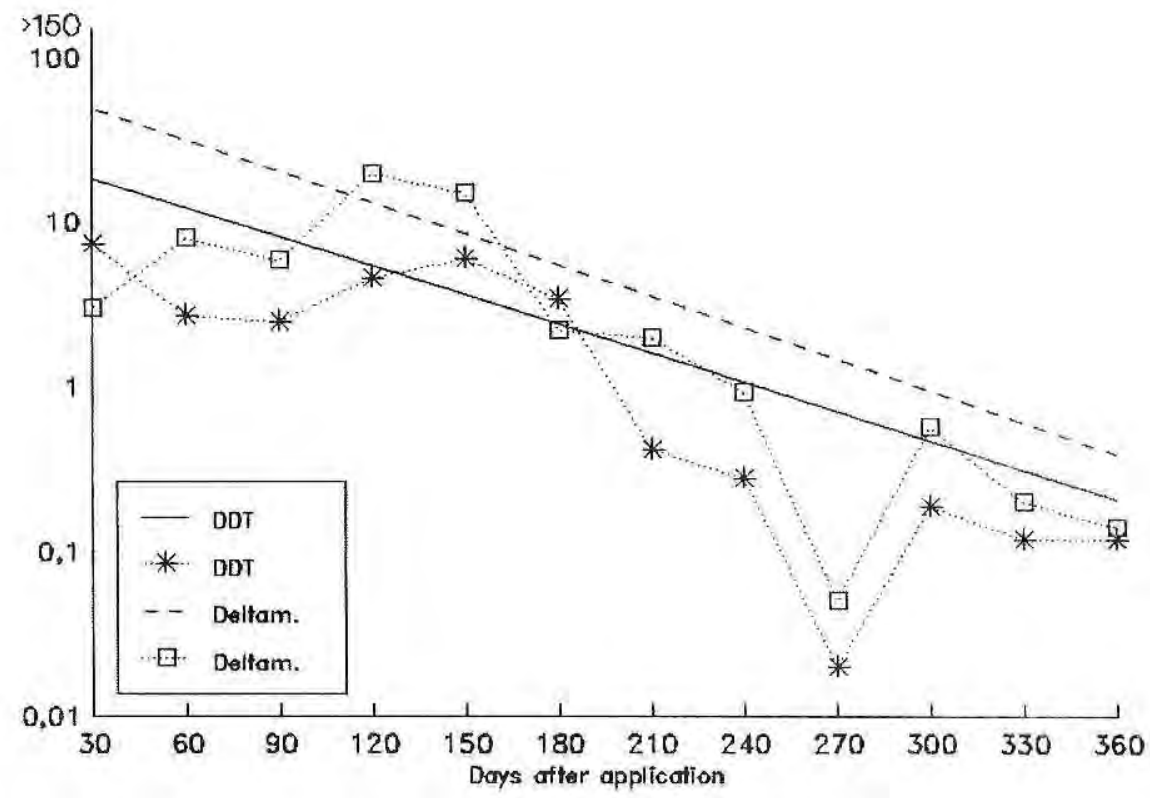

The lines indicate logistic regrassion cums

Figura 4. Mortality indices on wattle/daub at 24 hours.

indices predicted by regression, (Fig. 2), are analyzed, it can be seen that they are inferior on wattle/daub walls as compared to masonry and wood. This is an indication of of the low activity of both insecticides on this surface.

Our results were better than those obtained by Bitsindou (1982), who evaluated the residual power of deltametrine at $25 \mathrm{mg} / \mathrm{m}^{2}$ on a cement substrate and recorded a mortality of $88 \%$ four months after treatment. In Guatemala, under the same conditions, only $47 \%$ mortality was obtained after 167 days. In another experiment conducted in the city of Sucre, Bolivia, Saume et al. (1993) obsserved a 70\% mortality after 98 days on concrete surfaces.

High mortality figures on wooden surfaces have also been obtained in other countries. In the Philipines in 1979, using deltametrine at $10 \mathrm{mg} / \mathrm{m}^{2}$ on five different types of plant covered surfaces, $100 \%$ mortality was found 6 months after treatment. In Guatemala, using deltametrine at $25 \mathrm{mg} /$ $\mathrm{m}^{2}$ (wetable powder), $100 \%$ mortality was seen on wooden surfaces 167 days post treatment (Dartigues, 1987).

The results of this study reveal that wooden surfaces have higher mortality figures with both insecticides and that deltametrine has greater stability and with greater mortality than DDT.

Data obtained in the present study show that on the wattle/daub surfaces neither insecticide reached $90 \%$ mortality after 30 days. After 210 days, the activity of both insecticides was greatly reduced especialmente that of DDT (FW $=64.76$; $\mathrm{DDT}=27.10 \%$ ). Deltametrine lasted better on this type of wall. This finding is similar to that of Coosemans and Sales (1977) who compared the residual effect of deltametrine on dried mud with that 
of peermetrine and malathion. They concluded that deltametrine is more persistent than permetrine and equal to malathion. In an experiment done in China in 1982 by Guandong of the Provincial Institute of Parasitic Disease, the mortality on clay bricks did not exceed $3.3 \%$ after 22 days. Wood is the material that should be used in the construction of houses in areas of malarial endemicity, thus, deltametrine having greater residual power could be used only every 9 months. In this way, the costs of public health campaigns could be reduced.

\section{CONCLUSIONS AND RECOMMENDATIONS}

Wood: The action of deltametrine was superior to that of DDT except at 30 days post treatment when the latter showed a $100 \%$ mortality. On wooden surfaces, the drop in mortality was gradual up to 360 days with that for deltametrine usually higher.

Masonry: DDT showed a higher mortality up to 60 days at which time it activity decreased while the effectiveness of deltametrine appeared to increase. The activity of both insecticides dropped off after 240 days.

Wattle/daub: Neither insecticide showed as much as $90 \%$ mortality at 30 days. After 210 days, the deltametrine still showed a mortality of $65 \%$ compared to $27 \%$ for DDT.

\section{ACKNOWLEDGMENTS}

This research was supported by the Brazilian National Research Council (CNpq) and the Chemical Products Division of "Químicos Comércio e Indústria S.A."

\section{Literature cited}

Bitsindou, G. G. P. 1982. Impact des traitements insecticides (DELTAMETHRINE) sur la transmission du paludisme et sa morbidité dans un village des environs de Brazzaville (Rép. du Congo)-Thése de doctorat de 3 e cycle - Univ. Paris Sud (Orsay - France) - Congo.

Coosemans, M. H.; Sales, S. 1977. Stage IV evaluation of five insecticides - OMS-43,OMS1810,OMS-1821,OMS-1825 and OMS-1998against anopheline mosquitoes at the Soumousso experimental station, Bobo Dioulasso, Upper Volta. WHO/VBC/77.663.

Dartigues, V. 1987. Utilización de la deltametrina en el control de la malaria. Paris, Roussel-Uclaf Division Agrovet.77p.

Marrques, A. C.; Cárrdenas, G. H. 1994. Combate à malária no Brasil: evolução, situação atual e perpectivas. Rev. Soc. Bras. de Med. Trop.27: (Sup III)91-108.

PAHO/WHO (1991) Status of malaria programs in the Americas. XXXIX Report. Pan American Health Organization/World Health Organization, CD35/INF/2.130p.

Saume, F.; Hernandez, A.; Vera, J.; Salcedo, A.; Ledezma, M. 1993. Comportamiento del K-Othrine en el control de Anopheles aquasalis en el Estado Sucre (1987). Segundo Simposium Latino Americano sobre Biologia y control de vectores de enfermedades en Humanos (Resumos). Roussel, Estado Nueva Esparta, Venezuela.p.6.

Tadei, W. P.; Mascarenhas, B. M.; Podestá, M. G. 1983. Biologia de anofelinos amazônicos. VIII. Conhecimentos sobre a distribuição de espécies de Anopheles na região de TucuruiMarabá (Pará). Acta Amazonica, 13:103-140.

Tadei, W. P. 1993. Biologiade anofelinos amazônicos. XVIII. Considerações sobre as espécies de Anopheles (Culicidae), transmissão e controle da malária na Amazônia. Mem. Inst. Oswaldo Cruz. 